\title{
防窝剤フリルフラマイドの微生物的定量法の検討-II. 検液調製方法の検討
}

篠山茂行・鈴木郁子 (1966 年 3 男 22 日受理)

\section{A STUDY ON THE MICROBIOASSAY OF FURYLFURAMIDE AS FOOD PRESERVATIVES-II. PREPARATION METHOD OF TEST SOLUTION FOR DETERMINING OF FURYLFURAMIDE IN FISH PRODUCTS}

\author{
Shigeyuki SaSayama and Ikuko Suzuki*
}

\begin{abstract}
As part of the determination method of furylfuramide ( $F F$ ) in fish products, the preparation of the test solution for a microbioassay of FF which has been added to ground fish meat or fish sausage was studied, and following results were obtained.

The removal of water-soluble components from fish flesh shows no discernible effect of interference on the recovery of FF (Table 1). When the ground meat of whale is stored at $3 \pm 1^{\circ} \mathrm{C}$, the amount of FF decreased to one-tenth of the initial amount after 96 hours (Table 2). The decrease of FF is also recognized in the case of storage test of homogenated meat (Table 3), however, the recovery of FF seems to differ with different proportion of fish meat and water (Tables 4 and 5). In the preparation of supernatant to be tested from homogenate, the speed of centrifugation affects on the amount of FF in supernatant (Table 6).

On the basis of the results presented above, the following method of preparation of test solution was recommended:

To one part of sample such as fish sausage, is added three parts of DMF buffer solution, and the mixture blended for 1 minute by homogenizer. The homogenate obtained is centrifuged at 6000 r.p.m. for 15 minutes, and the supernatant is subjected to the determination of FF.
\end{abstract}

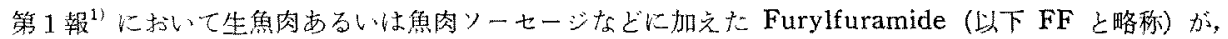

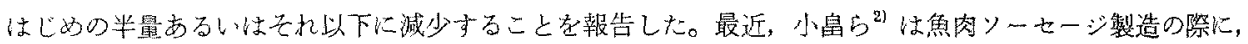
寸り身の調製中に添加された FF が減少すること，加熱还理後の製品々はさらに減少していることをみて

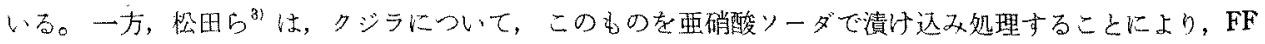
の残存量低下が防止できること，また，魚肉毇濁液中での FF 䁷の減少はシスティン溶液中でのそれと同

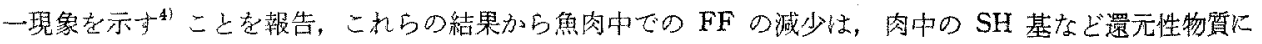
上つて罡元失活するた奴あつて，その際ミオグロビンが触媒的に澴元反応を促進することを推定している。

このよ5に, FF が魚肉成分によつて分解されるとすれば，微生物的定量法に際して，定量に供される試

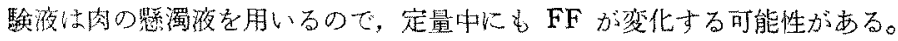

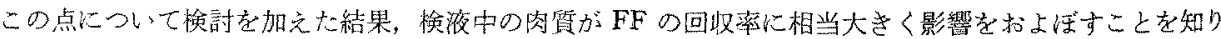

得たのでここに報告する。

柬海区水䃌研究所業績 B 450 号

*柬海区水産研究所 (Tokai Regional Fisheries Research Laboratory, Kachidoki, Chuo-ku, Tokyo) 


\section{実験方法むよび結果}

FF の定量方法第1 報”に報告したシリンダープレートを用いる微生物的定鼠法により行ない，抽出 剂および希䣋剂には DMF 緩衝液”を用いた。

水洗処理を施した魚肉からの FF の回收魚阁中のミオグロビンが FF 残存量低下の一原因に推定さ

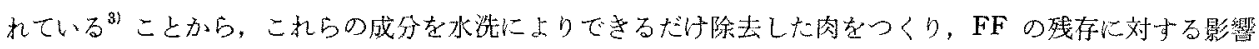

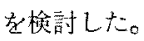

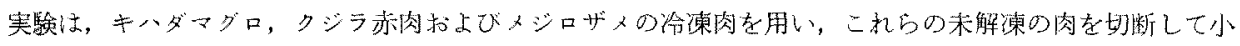
塊とし，さらに肉挽機にか村細碎する。これを詨照の 未水洗肉区とする。一方，同様細㸞した肉に8倍量の 水を添加し，ブレンダーで 2 分間然理ののち，遠心 (3000 r.p.m., 10 分) 寸る。得ら机る沈溊闪に8倍量

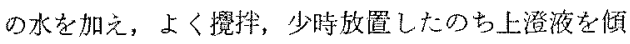
渴し，残りを再じ遠心して肉を集める。これを7回繰 り返して水に浮上する物質心上び水溶性部分をできる たけ除いた肉をつくる。これを水淩肉区とする。

雨区に FFを 50 ppm となるよらに加光てよく嬥

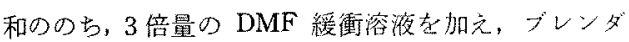
一で1分間処理，その肉彩濁液についてただりに FF 它定量する。

結果は Table 1 に示すよらに，FFの回収率は末

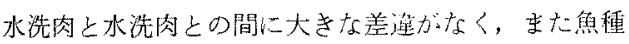
間にむ在とんど差遠がないしたがつて定童操作中心 失活住闪中のミオクロビン, 水溶性蛋白あるいは脂肪 などによつてはそれほど影製を受けないものと思われ 万。

魚肉に加えた FF の経時的変化 FF 索滺生物的方

Table 1. Effect washing of fish meat on the recovery of $\mathrm{FF}$ by microbioassay.

\begin{tabular}{c|c|c}
\hline \multirow{1}{*}{ Sample } & \multicolumn{2}{|c}{ Recovery rate of $\mathrm{FF}$} \\
\cline { 2 - 3 } & Not washed & Washed \\
\hline $\begin{array}{l}\text { Yellowfin tuna } \\
\text { (Kihadamaguro) }\end{array}$ & $37 \%$ & $35 \%$ \\
$\begin{array}{l}\text { Whale } \\
\text { (Kujira) }\end{array}$ & 39 & 35 \\
$\begin{array}{l}\text { Roundhead shark } \\
\text { (Mejirozame) }\end{array}$ & 42 & 39 \\
\hline
\end{tabular}

Note: The water-soluble component in $100 \mathrm{~g}$ of fish meat was exhaustively removed by washing with seven $800 \mathrm{~m} l$ portions of water, and the residue was used as washed meat. Initial concentration of $\mathrm{FF}$ in meat was adjusted to $50 \mathrm{ppm}$. The determination method of FF was virtually identical with that of previous paper ${ }^{1\}}$.
法によつて定量するときは，DMF 緩衝溶液老加えて

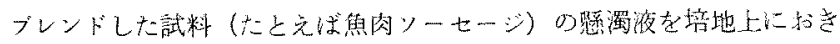
約 20 時間にわたつて放置士る操作が含ま机ている。肉非てのFFの举

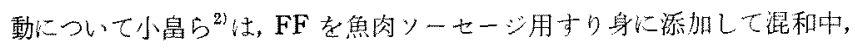

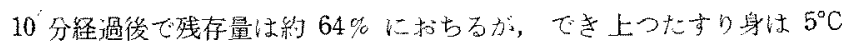
に4時閏放置してもその間になんらの減少を示ざず安定であると述へて いるか，4時間以上の变化柱不明である。そこで定量方法に閣連して肉 に添加したFF が長時間安定であるか，どらかる知るため，次の穾娩を 行なつた。

1. 生肉中での変化

FF の櫒度を $50 \mathrm{ppm}$ としたクジラ赤肉のすり身を嵒化ビニりデン ケーシンダに充填し， $3 \pm 1^{\circ} \mathrm{C}$ の烃蔵連に保存する。この試料老 24 時 閒経過ごとに取り出し，その都度 3 倍量のDMF 緩㣫液とともにブレ

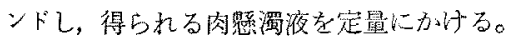

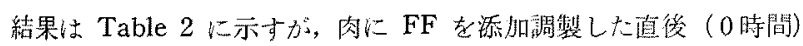
の検出染は $46 \%, 24$ 時閒後 $26 \%$ ，それ以降時間の経過とともに值線
Table 2. Change of recovery rate of $\mathrm{FF}$ in raw ground meat of whale during storage at $3 \pm 1^{\circ} \mathrm{C}$.

\begin{tabular}{c|c}
\hline $\begin{array}{c}\text { Storage time } \\
\text { (hours) }\end{array}$ & $\begin{array}{c}\text { Recovery } \\
\text { rate of FF }\end{array}$ \\
\hline 0 & $46 \%$ \\
24 & 26 \\
48 & 14 \\
72 & 7 \\
96 & 4 \\
\hline
\end{tabular}

Note: Initial concentration of $\mathrm{FF}$ was adjusted to $50 \mathrm{ppm}$. 


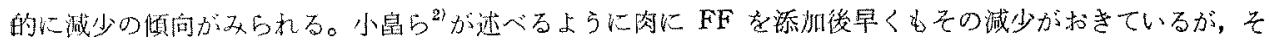
の绕も娍少は停止するこもなく，72 時間で $7 \%$ の残存を示すにすざない。

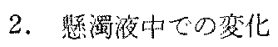

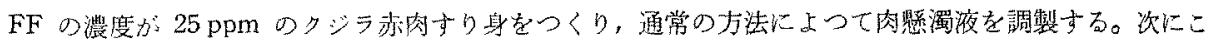

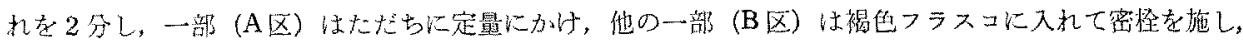

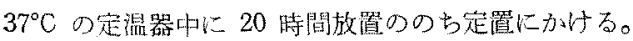

Table 3. Change of recovery rate of $F F$ in homogenate during storage.

\begin{tabular}{|c|c|}
\hline Test material & Recovery rate of FF \\
\hline (A) Homogenate immediately after preparation & $44 \%$ \\
(B) Homogenate after storage at $37^{\circ} \mathrm{C}$ for 20 hours & 22 \\
\hline
\end{tabular}

Note: FF concentration in whale meat was adjusted to $25 \mathrm{ppm}$.

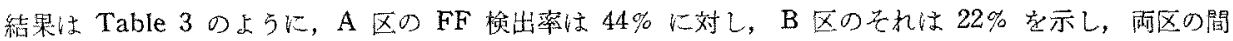

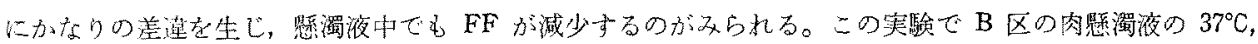

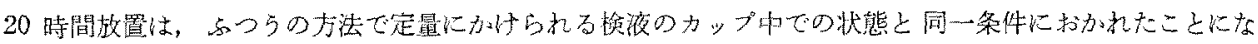

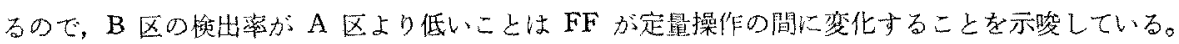

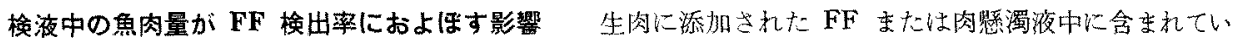

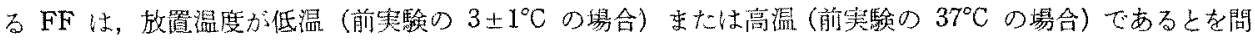
わず約 20〜24 時間経過後ではじかの添加量の䄪半量に減少することが明らかとなつたので，FFの検出率

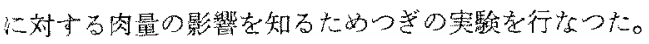

1. 肉量上FF 检出㸃との関係

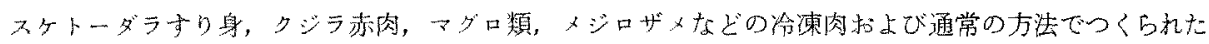

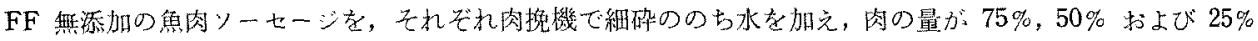

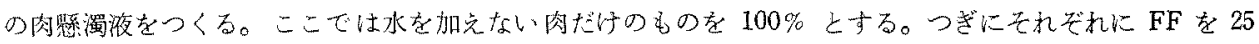
$\mathrm{ppm}$ となるように扣え，さらに3倍量の DMF 緩衝液を追加し，ブレンダー処理ののち、ただちに FFを 定量する。

結果は Table 4 に示す上らに，肉量が少なくなるにしたがつて检出率の上昇がみら机る。したがつて，

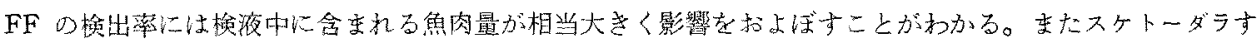

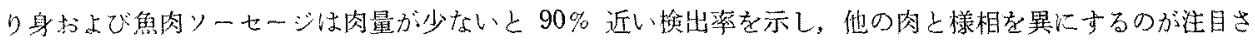
れる。

Table 4. Relation between the amount of fish meat and recovery rate of FF.

\begin{tabular}{|c|c|c|c|c|c|c|c|}
\hline \multirow{2}{*}{\multicolumn{2}{|c|}{$\begin{array}{l}\text { Mixing ratio of } \\
\text { meat and water }\end{array}$}} & \multicolumn{6}{|c|}{ Recovery rate of $\mathrm{FF}$} \\
\hline & & \multirow{2}{*}{$\begin{array}{l}\text { Alaska pollack } \\
\text { (frozen ground } \\
\text { meat of Sketo- } \\
\text { dara) }\end{array}$} & \multirow{2}{*}{$\begin{array}{c}\text { Whale } \\
\text { (Kujira) }\end{array}$} & \multirow{2}{*}{$\begin{array}{l}\text { Yellowfin } \\
\text { tuna } \\
\text { (Kihada- } \\
\text { maguro) }\end{array}$} & \multirow{2}{*}{$\begin{array}{l}\text { Big-eye } \\
\text { tuna } \\
\text { (Mebachi- } \\
\text { maguro) }\end{array}$} & \multirow{2}{*}{$\begin{array}{c}\text { Rotundhead } \\
\text { shark } \\
\text { (Mejiro- } \\
\text { zame) }\end{array}$} & \multirow{2}{*}{$\begin{array}{c}\text { Fish } \\
\text { sausage }\end{array}$} \\
\hline Meat & : Water & & & & & & \\
\hline 100 & 0 & $49 \%$ & $37 \%$ & $41 \%$ & $42 \%$ & $32 \%$ & $50 \%$ \\
\hline 75 & 25 & 58 & 45 & 48 & 44 & 50 & 54 \\
\hline 50 & 50 & 77 & 46 & 54 & 54 & 59 & 77 \\
\hline $25:$ & 75 & 90 & 62 & 64 & 64 & 68 & 93 \\
\hline
\end{tabular}

Note: To diluted meat, FF (25 ppm) was mixed, and the mixture was bleneded with extractant. 


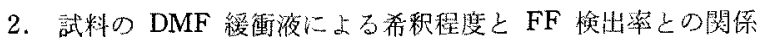

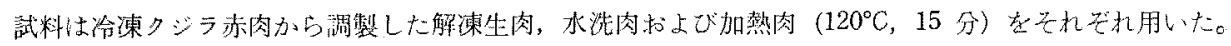

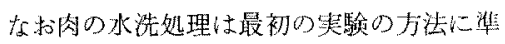
した。度た肉の加熱処理は，肉の殺菌をむ 考聋して高温加熱女採用した。それぞれの 処理肉に FF の濃度が $100 \mathrm{ppm} と な る$ よらに加えたのb，こ机圭2分し，一部は DMF 猨街波で4倍に，他の一部は8倍に 希釉し，ブレンダー処理，各肉照濁液を走 量放加各。

結果は Table 5 に双々る上5に，肉

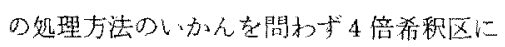
比して8倍希积区流い娭出率を示し，希 秋率を增大することにより回収率子增加し

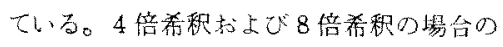

Table 5. Effect of dilution of sample on the recovery rate of $\mathrm{FF}$.

\begin{tabular}{l|c|c|}
\hline Sample* & \multicolumn{2}{|c|}{ Recovery rate of FF } \\
\cline { 2 - 3 } & $\begin{array}{c}\text { 4times of DMF } \\
\text { buffer was used }\end{array}$ & $\begin{array}{c}8 \text { times of DMF } \\
\text { buffer was used }\end{array}$ \\
\hline Raw meat & $46 \%$ & $62 \%$ \\
$\begin{array}{c}\text { Washed meat } \\
\text { Cooked meat } \\
\text { (heated at } \\
120^{\circ} \mathrm{C} \text { for } \\
15 \text { minutes })\end{array}$ & 45 & 53 \\
\hline
\end{tabular}

Note: * Whale meat

FF added to raw, washed and cooked meat were $100 \mathrm{ppm}$ respectively.

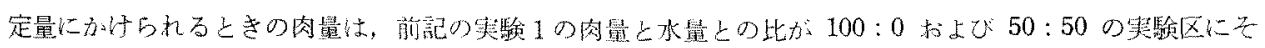

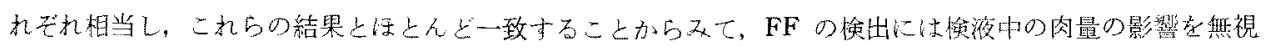
できないとが再確形された。

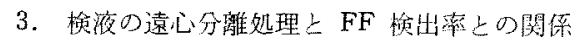

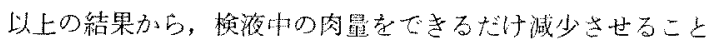

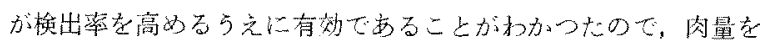
隇少させる简易な手段として邀心分離をえらび，さらにもの炏果 を検討することとした。

まず，肉焦濁液を遠心分睢する際の遠心機の回転数上FF娭出

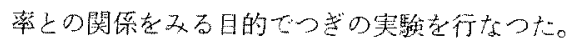

FF 濃度 $25 \mathrm{ppm}$ のクジラ赫肉のすり身をつくり, 涌常の方法

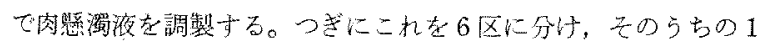

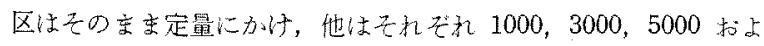

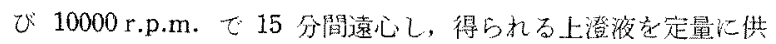
する

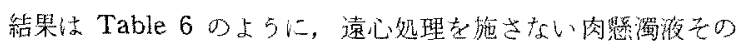

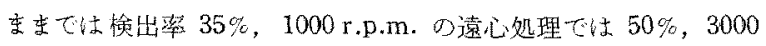

Table 6. Relation between centrifugal speed and recovery rate of $\mathrm{FF}$.

\begin{tabular}{c|c}
$\begin{array}{c}\text { Centrifugal speed } \\
\text { (r. p. m.) }\end{array}$ & $\begin{array}{c}\text { Recovery rate } \\
\text { of FF }\end{array}$ \\
\hline $\begin{array}{c}\text { (homogenate) } \\
1000\end{array}$ & $35 \%$ \\
3000 & 53 \\
5000 & 62 \\
7000 & 64 \\
10000 & 59 \\
\end{tabular}

Note: Initial concentration in whale meat was adjusted to $25 \mathrm{ppm}$.

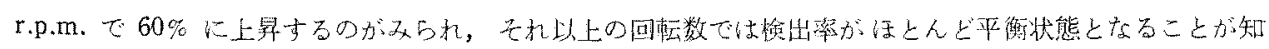

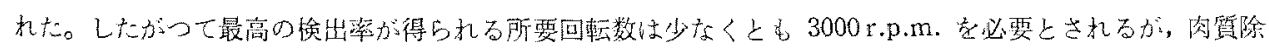

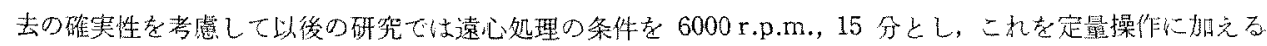
こと化した。

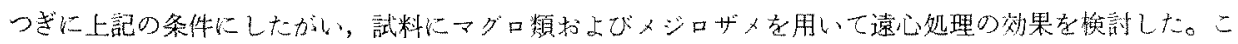

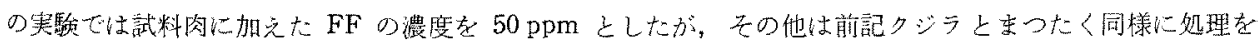
行なつた。

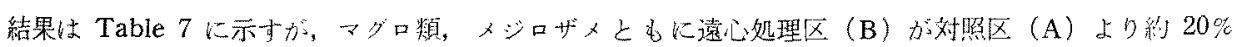

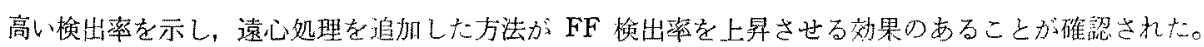

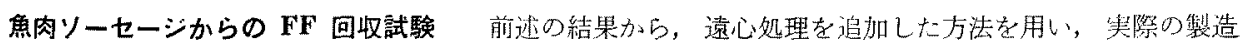
条件に準じてつくられた魚肉ンーセージについて FF の定量を行なつた。 
Table 7. Effect of centrifuging of homogenate on the recovery rate of FF.

\begin{tabular}{l|ccc}
\multicolumn{1}{c|}{ Test material } & \multicolumn{2}{c}{ Recovery rate of FF } \\
\hline $\begin{array}{l}\text { Yellowfin } \\
\text { tuna }\end{array}$ & $\begin{array}{c}\text { Big-eye } \\
\text { tuna }\end{array}$ & $\begin{array}{c}\text { Roundhead } \\
\text { shark }\end{array}$ \\
\hline $\begin{array}{l}\text { (A) Homogenate } \\
\text { (B) Supernatant (homogenate was centrifuged at } 6000 \\
\text { r.p. m. for 15 minutes) }\end{array}$ & $61 \%$ & $31 \%$ & $34 \%$ \\
\hline
\end{tabular}

Note: FF concentration in raw fish meat was adjusted to $50 \mathrm{ppm}$.

Homogenate or supernatant obtained from homogenate was tested.

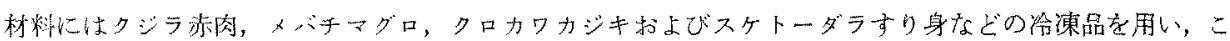

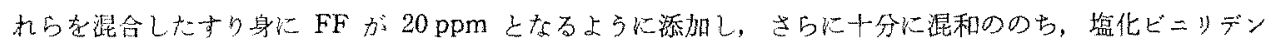
ケーシンダに詰め, $90^{\circ} \mathrm{C} て ゙ 60$ 分間加蓺, 水泠して㹕品とする。

でき上つた魚肉ンーセージ肉挽機で細砕し，その $10 \mathrm{~g} に 30 \mathrm{ml}$ の DMF 緩衝液を加充てブレンダー

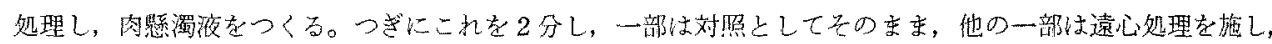
それぞれについてFF を定量する。

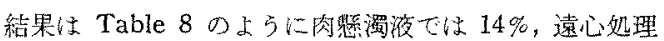
を施した上澄液では2 $25 \%$ の娭出率を示し，魚㤏ンーセ一 ジついても遠心処理が高い㛟出率を得ている。ただし， 今までの契娩て得られている生肉の場合上り低い娭出率を 示しているこ上が注目される。この実験てはFF の添加量 在使用基準の $20 \mathrm{ppm}$ としたが，检出量が上澄液からでも $5 \mathrm{ppm}$ 程度を示し，これは実㵋值では $1.25 \mathrm{ppm}$ に当た るので，FF の最低掵出限界澧度約 1 ppm に近い值とな

Table 8. Recovery test of FF in fish sausage prepared commercially. つている。

\begin{tabular}{l|c}
\hline Test solution & Recovery rate of FF \\
\hline Homogenate & $14 \%$ \\
Supernatant & 25 \\
\hline
\end{tabular}

Note: Initial FF concentration was adjusted to $20 \mathrm{ppm}$.

考察

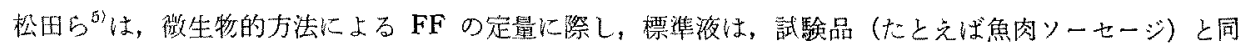
一組成の FF 不含のもの在用意し，こ机各濃度の FF を含む $10 \%$ DMF 水溶液を 3 倍量加之て調製し

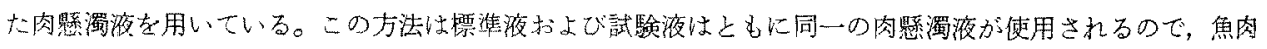
成分の影柏は相殺されることになり，定量方法としては一応問題なくみえる。しかし，実際には食品検査の 立場からみると，多〈は組成未知の製品が检定汇供されるので，定量の都度試験品と同一組成の対照品をお くことは極好て困難の上5汇思加れ。

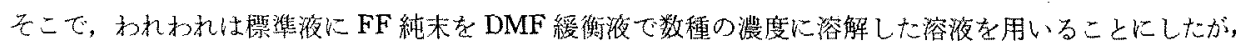
この場合試駼液に肉懸濁液を供すると肉質が介在するのでその影響が㬐念される。この点について, 本研究

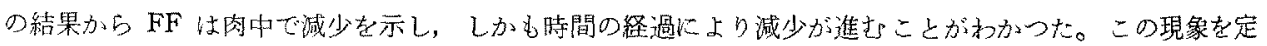

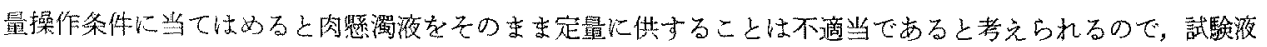

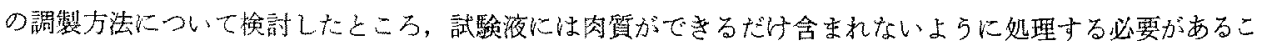

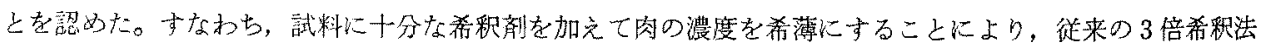
より高い検出率を得ることができる。しかし，魚肉ソ一セージについては，FF の使用基準は $0.02 \mathrm{~g} / \mathrm{kg}$ に 規定されていること, 製造中に FF が減少すること, 製品の盯蔵中減少が進むこと五788, 一方, 微生物 的定量法による FF の检出限界は最低 $1 \mathrm{ppm}$ 付近であることなどを考虑すると, 希釈刜の添加量はおのず から制限される。これに対し，遠心分離処理は十分に効果を浔めることができるので，定量法に 6000 r.p.m., 
15 分關の遠心分離処理を採用することは有效である。

要約

シリンダープレートを用いる微生物的方法で FF を定量する場合の渙液の調製方法について，大ケト一 ダラすり身，マグロ類、クジラ赤肉拈よびメジロザメを試料に用いて换討した。

1. 魚肉中の水さらしによつて除去される血液, 血色素, 水溶性㔻白ならびに脂肪の一部晾るいは土キ又 成分などは FF の定量操作に民れほど大きな影響はおよ淁さない。

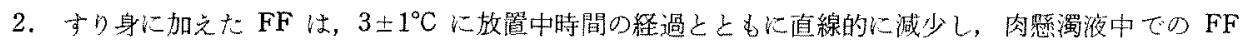
ま同様古变化をする。

3，挨液比含有される肉の量に上つて FF 検出率が变化し，肉の量が希薄になるにしたがつて検出率は

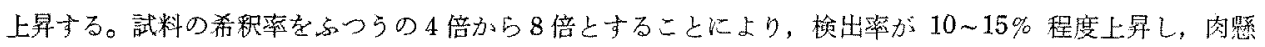
濁液の遠心分離処理（6000 r.p.m., 15 分）は常法にくらべ $20 \%$ 程度の検出率の增加を示す。

4. FF の使用基集にしたがつてつくられた魚肉ン一七一ジ中の FF 残存量依，常法では $2.8 \mathrm{ppm}$ (14 \%), 遠心処理法では $5 \mathrm{ppm}(25 \%)$ であつた。

終わりに FF の入手にご援助いただいた上野製薬株式会社に感謝の意老表する。

\section{文献}

1) 簿山茂行・鈴木郁子・天野鹿之：本誌，32，267 273 (1966).

2）小甶 渾・松田敏生：本誌，31，214２18 (1965).

3）烃田敏生・小富 渥: " 31, 365 369 (1965).

4) 松田敏生: 醴酸工学䧴誌, 43，426 431 (1965).

5) 松㽢敏生. 小香 渥: 本誌, 31，208～213 (1965).

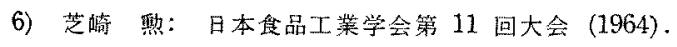

7) 篠山茂行・鉿木郁子: 未発表.

8）小白 渥：本誌，31，365 369 (1965). 